\title{
IDENTIFIKASI KANDIDAT MARKA MHC I PADA IKAN LELE (Clarias sp.) TAHAN INFEKSI Aeromonas hydrophila
}

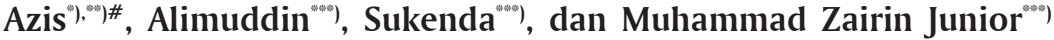 \\ ") Mahasiswa Program Doktor, Departemen Budidaya Perairan, Institut Pertanian Bogor \\ ") Program Studi Budidaya Perikanan, Fakultas Perikanan dan Ilmu Kelautan, Universitas Borneo, Tarakan \\ $\rightarrow$ Departemen Budidaya Perairan, Institut Pertanian Bogor
}

(Naskah diterima: 29 April 2015; Revisi final: 29 Mei 2015, Disetujui publikasi: 5 Juni 2015)

\begin{abstract}
ABSTRAK
Penyakit motile aeromonad septicemia disebabkan oleh bakteri Aeromonas hydrophila dapat menyebabkan kematian tinggi pada ikan lele (Clarias sp.). Penelitian ini dilakukan untuk mendapatkan kandidat marka MHC I dalam seleksi berbasis marka molekuler untuk menghasilkan ikan lele varietas sangkuriang tahan infeksi bakteri $A$. hydrophila. Sebanyak 200 ekor ikan lele dengan bobot $60 \pm 5 \mathrm{~g}$ diuji tantang dengan menyuntikkan bakteri $A$. hydrophila dengan konsentrasi $10^{6} \mathrm{cfu} / \mathrm{mL}$ sebanyak $0,1 \mathrm{~mL} / \mathrm{ekor}$ ikan. Hasil uji tantang menunjukkan sintasan ikan lele sebesar 54\% (14 ekor ikan tanpa luka, dan 94 ekor ikan luka dan kemudian sembuh). Tujuh pasang primer didesain berdasarkan sekuen gen major histocompatibility complex (MHC) I ikan Clarias gariepinus yang terdapat di Bank Gen. DNA diekstraksi dari jaringan sirip ekor ikan hidup dan yang mati, kemudian dijadikan cetakan dalam amplifikasi PCR. Hasil PCR menggunakan salah satu set primer menunjukkan adanya pita DNA spesifik berukuran sekitar 300, 500, dan 1.000 bp pada ikan yang hidup pascatantang. Hasil analisis sekuen menggunakan basic local alignment search tools (BLAST) menunjukkan bahwa produk PCR tersebut memiliki kesamaan 69\%-88\% dengan gen MHC I ikan C. gariepinus. Dengan demikian, fragmen MHC I tersebut dapat menjadi marka molekuler ikan lele tahan infeksi $A$. hydrophila.
\end{abstract}

KATA KUNCI: ikan lele, marka molekuler, Aeromonas hydrophila, MHC I

ABSTRACT: Identification of MHC I marker candidate in catfish (Clarias sp.) Resistant Aeromonas hydrophila infection. By: Azis, Alimuddin, Sukenda, and Muhammad Zairin Junior

\begin{abstract}
Motile aeromonad septicemia disease is caused by the bacterium Aeromonas hydrophila can cause high mortality in catfish (Clarias sp.). This study was conducted to obtain a MHC I marker candidate for marker based selection to generate A. hydrophila resistance of sangkuriang catfish. A total of 200 fishs with body weight $60 \pm 5 \mathrm{~g}$ were challenged by intraperitoneally injecting $0.1 \mathrm{~mL} / \mathrm{fish}$ with A. hydrophila at a dose of $10^{6} \mathrm{cfu} / \mathrm{mL}$. Challenge test results showed the viability of fish was 54\% (14 fishs survived without injure, and 94 fishs recovered from injured). Seven set primers were designed based on database gene sequences of major histocompatibility complex (MHC) I of Clarias gariepinus. Genomic DNA was extracted from caudal fin tissue of living and the dead fish, and then used as template in PCR amplification. The PCR results using a set of primer showed specific DNA bands of approximately 300, 500 and $1,000 \mathrm{bp}$ in the survived fish. The results of sequence analysis using the basic local alignment search tools showed that the nucleotide sequence of those PCR products had similarity of 69\%-88\% with MHC I genes of C. gariepinus. As conclusion, MHC I could be used as a molecular marker of A. hydrophila resistance catfish.
\end{abstract}

KEYWORDS: $\quad$ catfish, molecular markers, Aeromonas hydrophila, MHC I

\section{PENDAHULUAN}

Penyakit yang biasa menyerang ikan lele adalah motile aeromonad septicemia yang disebabkan oleh in-

\# Korespondensi: Mahasiswa Program Doktor, Departemen Budidaya Perairan, Institut Pertanian Bogor. Jl. Lingkar Akademik Kampus IPB Bogor 16680, Indonesia. Tel.: + (0251) 8622941

E-mail: azis.borneo@gmail.com; alimuddin@ipb.ac.id feksi bakteri Aeromonas hydrophila (Allan \& Stevenson, 1981). Infeksi $A$. hydrophila dapat menyebabkan kematian ikan dalam jumlah besar (Angka et al., 2004). Saat ini telah dikembangkan vaksin untuk A. hydrophila yang dikenal dengan nama vaksin "Aero" dalam bentuk vaksin inaktif. Kelemahan vaksin tradisional, terutama vaksin yang dilemahkan berisiko infeksi karena bakteri atau virus yang telah dilemahkan ber- 
potensi menjadi patogen, biaya relatif mahal khususnya untuk ikan air tawar dan perlu dilakukan vaksinasi ulang (Mulia et al., 2004). Penggunaan benih ikan lele tahan infeksi A. hydrophila secara genetik merupakan alternatif solusi. Namun demikian, hingga saat ini belum ada varietas ikan lele tahan bakteri patogen tersebut.

Ikan tahan infeksi penyakit dapat dihasilkan melalui aplikasi seleksi secara konvensional seperti yang telah dilakukan dalam pembuatan ikan mas Krasnodar (Cyprinus carpio) resisten dropsy (Kirpichnikov et al., 1993). Namun demikian, waktu yang dibutuhkan relatif lama; ikan mas tahan penyakit dropsy diperoleh pada generasi 9 (Kirpichnikov, 1999). Pendekatan lain yang dapat dilakukan untuk menghemat waktu adalah seleksi dengan bantuan marka molekuler (marker assisted selection, MAS) (Xu et al., 2011). Metode ini telah berhasil digunakan untuk membuat ikan mas tahan infeksi virus KHV (Alimuddin et al., 2011). Marka molekuler yang digunakan adalah Cyca-DAB1*05 yang terkait sistem imun, dan termasuk kelompok gen major histocompatibility complex class II (MHC II). MHC II berperan dalam aktivasi sel-sel fagosit untuk memproduksi antibodi dan mengaktivasi sistem imun yang terlibat dalam eliminasi parasit dan bakteri, dan menetralkan virus (Rakus, 2008). Kelompok MHC lain yang terlibat dalam sistem imun adalah MHC I.

Major histocompatibility complex (MHC) berperan dalam komunikasi antara sel dan respons imun organisme vertebrata, termasuk kemampuan merespons tipe antigen (Germain, 1994). MHC bersifat polimorfik dan terdapat pada semua individu (Roitt, 1994). Polimorfisme MHC tinggi sangat membantu dalam proses seleksi berbasis MAS. Selanjutnya, polimorfisme tinggi pada MHC secara langsung berhubungan dengan kemampuan molekul untuk berikatan dengan urutan peptida tertentu, berfungsi menjamin sintasan organisme dalam hubungannya dengan sejumlah besar agen patogen yang ada dalam lingkungan (Choi \& Schwartz, 2007). Dengan demikian, MHC banyak digunakan untuk mendapatkan ikan tahan infeksi penyakit di antaranya adalah: MHC I pada ikan rainbow trout (Oncorhynchus mykiss) dan ikan salmon Atlantik (Salmo salar) (Aoyagi et al., 2002; Grimholt et al., 2002), kombinasi MHC I dan MHC II untuk penyakit infectious salmon anaemia virus pada ikan salmon Atlantik (Kjoglum et al., 2006), dan gen MHC I $\alpha$ dan ketahanan terhadap infectious haematopoietic necrosis virus pada ikan rainbow trout (Li et al., 2013). Aplikasi MAS di Indonesia telah dilakukan pada ikan mas dengan menggunakan MHC II terkait daya tahan terhadap infeksi koi herpes virus (Alimuddin et al., 2011). Amplifikasi PCR dilakukan menggunakan primer spesifik didesain berdasarkan sekuen gen MHC II yang ada di Bank Gen, dengan cetakan DNA dari ikan yang hidup dan mati pascatantang. Pita DNA produk PCR yang berbeda antara ikan yang hidup dan mati pascatantang merupakan MAS. Dengan pendekatan yang sama dengan Alimuddin et al. (2011), penelitian ini dilakukan untuk mendapatkan marka molekuler berupa primer yang dapat membedakan antara ikan lele tahan dan rentan infeksi $A$. hydrophila.

\section{BAHAN DAN METODE}

\section{Penyiapan Isolat $A$. hydrophila}

Isolat bakteri $A$. hydrophila dengan kode AHL 110306-3 diperoleh dari Balai Penelitian dan Pengembangan Budidaya Air Tawar, Bogor. Peningkatan virulensi $A$. hydrophila dilakukan dengan menyuntikkan $A$. hydrophila dosis $0,1 \mathrm{~mL} / \mathrm{ekor}$ pada tiga ekor ikan lele di bagian intramuskuler, proses penyuntikan dilakukan tiap tiga hari sebanyak tiga kali. Setelah 24 jam, ikan yang terserang $A$. hydrophila ditandai dengan adanya dropsy dibedah, organ hati, limpa dan ginjal ikan diambil, kemudian digerus untuk menghasilkan suspensi bakteri. Selanjutnya, dengan menggunakan jarum Ose, bakteri diambil dan dibiakkan pada media selektif Rimler Shott, diinkubasi pada suhu $37^{\circ} \mathrm{C}$ selama 24 jam. Bakteri A. hydrophila dipindahkan ke media tryptic soy agar (TSA) miring, diinkubasi selama 24 jam pada suhu $28^{\circ} \mathrm{C}$. Sebelum digunakan, bakteri $A$. hydrophila dikultur menggunakan media tryptic soy broth (TSB) selama 24 jam pada suhu $28^{\circ} \mathrm{C}$. Bakteri dipanen menggunakan sentrifugasi selama 15 menit dengan kecepatan $3.000 \mathrm{rpm}$, dan disuspensi dengan phosphate buffer saline (PBS). Kepadatan bakteri dihitung menggunakan spektrofotometer pada panjang gelombang $540 \mathrm{~nm}$. Bakteri diencerkan dengan PBS hingga mencapai konsentrasi yang diinginkan, selanjutnya bakteri siap digunakan untuk uji tantang. Morfologi dan karakteristik biokimia bakteri yang tumbuh diamati untuk memastikan bakteri tersebut adalah $A$. hydrophila (Tabel 1), mengikuti prosedur standar SNI 7303:2009.

\section{Penentuan $\mathrm{LD}_{50}$}

Nilai $\mathrm{LD}_{50}$ digunakan dalam uji tantang. Penentuan LD $_{50}$ dilakukan dengan menyuntik ikan lele sangkuriang (berukuran $60 \pm 5 \mathrm{~g}$ ) dengan bakteri $A$. hydrophila sebanyak $0,1 \mathrm{~mL} /$ ekor secara intramuskuler dengan konsentrasi bakteri berbeda, yaitu: $10^{4}$, $10^{5}, 10^{6}, 10^{7}$ dan $10^{8} \mathrm{cfu} / \mathrm{mL}$. Sebanyak 45 ekor ikan lele digunakan untuk masing-masing perlakuan, dan setiap perlakuan diulang tiga kali. Uji tantang dilakukan selama tujuh hari, kematian ikan dicatat setiap hari dan $\mathrm{LD}_{50}$ dihitung pada akhir percobaan menggunakan metode Reed \& Muench (1938). 
Tabel 1. Pengujian gram dan uji biokimia bakteri Aeromonas hydrophila pascatantang sesuai prosedur standar SNI (2009) No. 7303:2009

Table 1. Gram and biochemical tests in Aeromonas hydrophila post-challenged of catfish followed standard procedure of (SNI 2009) No. 7303:2009

\begin{tabular}{|c|c|c|c|c|c|c|c|}
\hline \multirow{2}{*}{$\begin{array}{l}\text { Isolat } \\
\text { Isolate }\end{array}$} & \multicolumn{4}{|c|}{ Morfologi koloni (Morphology of colony) } & \multicolumn{3}{|c|}{ Uji biokimia (Biochemical test) } \\
\hline & $\begin{array}{l}\text { Warna } \\
\text { Color }\end{array}$ & $\begin{array}{c}\text { Elevasi } \\
\text { Elevation }\end{array}$ & $\begin{array}{l}\text { Gram } \\
\text { Gram }\end{array}$ & $\begin{array}{c}\text { Motilitas } \\
\text { Motility }\end{array}$ & $\begin{array}{l}\mathrm{O} / \mathrm{F} \\
\mathrm{O} / \mathrm{F}\end{array}$ & $\begin{array}{c}\text { Oksidase } \\
\text { Oxidase }\end{array}$ & $\begin{array}{l}\text { RS } \\
R S\end{array}$ \\
\hline $\begin{array}{l}\text { Isolat awal } \\
\text { Initial isolate }\end{array}$ & $\begin{array}{l}\text { Krem } \\
\text { Cream }\end{array}$ & $\begin{array}{l}\text { Cembung } \\
\text { Convex }\end{array}$ & - & + & $\mathrm{F}$ & + & + \\
\hline A & Krem (Cream) & Cembung (Convex) & - & + & $\mathrm{F}$ & + & + \\
\hline B & Krem (Cream) & Cembung (Convex) & - & + & $\mathrm{F}$ & + & + \\
\hline $\mathrm{C}$ & Krem (Cream) & Cembung (Convex) & - & + & $\mathrm{F}$ & + & + \\
\hline
\end{tabular}

Keterangan (Note):

$\mathrm{O} / \mathrm{F}=$ Oksidasi fermentasi (Oxidative fermentative); RS = Rimler Shott

\section{Penapisan Ikan Lele Tahan Infeksi $A$. hydrophila}

Sebanyak 200 ekor ikan lele sangkuriang berukuran $60 \pm 5 \mathrm{~g}$ diuji tantang dengan bakteri $A$. hydrophila menggunakan dosis $\mathrm{LD}_{50}$. Ikan dibagi ke dalam lima bak bervolume 1 ton, dengan kepadatan 40 ekor/bak. Pengamatan ikan yang mati, dan tahan infeksi $A$. hydrophila dilakukan selama tujuh hari. Selanjutnya ikan dipelihara selama 30 hari dalam wadah volume satu ton sebelum dipindahkan ke bak pembesaran. Selama pemeliharaan ikan ditempatkan dalam ruang karantina ikan dan menggunakan air sumur bor.

DNA genom diekstraksi dari sirip ikan yang hidup dan ikan yang paling cepat mati pascatantang. Ekstraksi DNA dilakukan menggunakan kit isolasi DNA (Puregene, Minneapolis, USA) mengikuti prosedur dalam manual. DNA dilarutkan dengan sterile distillated water (SDW), kemudian disimpan dalam lemari beku $-20^{\circ} \mathrm{C}$ hingga akan digunakan untuk proses PCR.

\section{Desain Primer}

Tujuh set primer dirancang dengan menyejajarkan 20 alel ikan lele C. gariepinus (Bank Gen No. EU 714302 s.d EU714321) yang terkait dengan gen MHC I. Penyejajaran sekuen dilakukan menggunakan program GENETYX versi 7.0, dengan tujuan untuk memperoleh kandidat primer forward dan reverse spesifik.

\section{Identifikasi Ikan Lele Pembawa dan Analisis Sekuen Gen MHC}

PCR dilakukan dengan volume akhir reaksi $25 \mu \mathrm{L}$, yang terdiri atas 10x bufer Tag DNA polymerase 2,50 $\mu \mathrm{L}$, dNTPs $2 \mu \mathrm{L}$, primer reverse dan forward masingmasing 2,00 $\mu \mathrm{L}$, Tag DNA polymerase 0,25 $\mu \mathrm{L}$, SDW $17,25 \mu \mathrm{L}$, dan sampel DNA sebanyak $1 \mu \mathrm{L}$. Program amplifikasi PCR yang digunakan adalah pengkondisian awal pada suhu $94^{\circ} \mathrm{C}$ selama lima menit; 35 siklus
PCR dengan denaturasi pada suhu $94^{\circ} \mathrm{C}$ selama 30 detik, annealing pada suhu $55^{\circ} \mathrm{C}$ selama 30 detik, dan ekstensi pada suhu $72^{\circ} \mathrm{C}$ selama satu menit; dan ekstensi akhir pada suhu $72^{\circ} \mathrm{C}$ selama tujuh menit. Sebagai kontrol internal loading DNA digunakan primer $\beta$-aktin (Alimuddin et al., 2008). Setelah mesin menjadi dingin (sekitar $4^{\circ} \mathrm{C}$ ), tabung mikro dikeluarkan dari mesin PCR. Elekroforesis dilakukan dengan menggunakan gel agarosa $2 \%(\mathrm{w} / \mathrm{v})$, pada tegangan 70 volt selama 90 menit. DNA divisualisasi dengan menggunakan gel red (Biotum Inc. California, USA) dan disinari cahaya ultraviolet.

Produk PCR kemudian disekuensing di Laboratorium $1^{\text {st }}$ Base Sequencing INT-Singapura menggunakan mesin ABI PRISM 3730 XL (Genetic Analyzer Develop by Applied Biosystem, USA). Hasil sekuensing dianalisis menggunakan BLAST untuk memperoleh kemiripan sekuen yang ada di Bank Gen.

\section{Analisis Hematologi}

Analisis hematologi dilakukan sebagai data pendukung. Sebanyak sembilan ekor ikan mewakili setiap perlakuan, diambil darahnya dengan cara menyedot darah menggunakan spuit ukuran $1 \mathrm{~mL}$ (telah dibilas dengan natrium sitrat $3 \%$ sebagai antikoagulan) pada pembuluh darah yang terletak di bawah tulang vertebrata di daerah vena kaudalis. Pengambilan sampel darah dilakukan setiap hari selama uji tantang dengan $A$. hydrophila. Sebelum pengambilan darah, ikan terlebih dahulu dibius dengan minyak cengkeh dosis 0,04 mg/L. Darah dimasukkan ke dalam tabung polietilen yang telah dibilas dengan natrium sitrat. Selanjutnya dilakukan pengamatan total eritrosit, total leukosit, kadar hemoglobin, dan kadar hematokrit. Jumlah eritrosit, dan total leukosit, dihitung menggunakan metode Blaxhall dan Daisley (1973). Kadar hemoglobin diukur menggunakan me- 
tode Sahli (Wedenmeyer \& Yasutake, 1977). Kadar hematokrit diukur menggunakan metode Siwicki \& Anderson (1993).

\section{HASIL DAN BAHASAN}

\section{Penentuan $\mathrm{LD}_{50}$}

Hasil uji LD $_{50}$ bakteri $A$. hydrophila pada ikan lele sangkuriang tersaji pada Gambar 1. Hasil pengamatan menunjukkan bahwa jumlah dan waktu mortalitas ikan yang terpapar berbeda-beda. Mortalitas tertinggi terjadi pada konsentrasi bakteri $10^{8} \mathrm{cfu} / \mathrm{mL}$ $(92,6 \pm 4,3 \%)$, kemudian berturut-turut pada konsentrasi bakteri $10^{7} \mathrm{cfu} / \mathrm{mL}(68,9 \% \pm 3,3 \%), 10^{6} \mathrm{cfu} / \mathrm{mL}$ $(52,6 \pm 3,9 \%), 10^{5} \mathrm{cfu} / \mathrm{mL}(23,7 \pm 1,9 \%)$, dan $10^{4} \mathrm{cfu} / \mathrm{mL}$ $(6,7 \pm 1,0 \%)$. Dari hasil perhitungan menggunakan metode Reed \& Muench (1938), diperoleh $\mathrm{LD}_{50}$ bakteri $A$. hydrophila sebesar $10^{5,9} \mathrm{cfu} / \mathrm{mL}$ dibulatkan menjadi $10^{6} \mathrm{cfu} / \mathrm{mL}$. Dengan demikian, konsentrasi bakteri $A$. hydrophila yang digunakan dalam penelitian selanjutnya adalah sebesar $10^{6} \mathrm{cfu} / \mathrm{mL}$. Mortalitas ikan lele yang terpapar bakteri $A$. hydrophila sangat tergantung pada kepadatan bakteri, kondisi ikan yang terpapar, dan lama waktu ikan terpapar.

\section{Penapisan Ikan Lele Tahan Infeksi $A$. hydrophila}

Mortalitas ikan lele sangkuriang pascatantang pada setiap bak adalah relatif sama $(42,5-60,0 \%)$ dengan rerata sintasan adalah 50\%. Secara total, dari 200 ekor ikan yang diujitantang, diperoleh 108 ekor ikan yang hidup. Mortalitas tertinggi terjadi pada hari ke3 dan 4 uji tantang. Pada hari ke-6 ikan yang terinfeksi mulai menunjukkan gejala luka yang berangsurangsur sembuh, dan kematian ikan mulai berkurang. Selain itu, berdasarkan pengamatan secara visual pada ikan yang hidup hingga akhir pengamatan, diperoleh sebanyak 14 ekor ikan termasuk kategori sangat tahan ( $R$, tidak ada luka), dan 94 ekor ikan kategori tahan (LS, luka kemudian sembuh).

\section{Analisis Marka Molekuler}

Di antara tujuh set primer yang diuji, diperoleh satu set primer yang menghasilkan produk PCR spesifik bagi ikan yang hidup pascatantang (Gambar 2). Ikan lele kategori tahan (LS1-LS5) dan sangat tahan (R1-R5) memiliki pita DNA spesifik berukuran sekitar 300 bp, 500 bp dan 1.000 bp. Ikan lele yang mati (M1M5) dan PCR tanpa DNA (N) tidak menunjukkan produk PCR pada ukuran DNA tersebut. Sementara itu, PCR menggunakan $\beta$-aktin sebagai kontrol internal menghasilkan pita DNA dengan ukuran sama untuk semua sampel, yakni sekitar 200 bp.

Hasil penyejajaran (alignment) nukleotida produk PCR pada posisi pita sekitar 500 dan 1.000 bp menunjukkan banyak kemiripan sekuen antara keduanya, khususnya pada sekuen sekitar 350 bp (Gambar 3). Sementara itu, kemiripan nukleotida produk PCR berukuran sekitar 300 bp dengan 500 bp adalah relatif rendah (Gambar 4). Demikian juga antara produk PCR ukuran sekitar 300 bp dengan 1.000 bp, kemiripannya relatif rendah (hasil tidak ditampilkan).

Analisis BLAST dilakukan untuk menguji kemiripan sekuen produk PCR dari penelitian ini dengan data yang ada di bank gen. Hasil analisis BLAST menunjukkan bahwa ketiga produk PCR spesifik ikan lele sangkuriang bertahan hidup dalam uji tantang dengan A. hydrophila memiliki kemiripan tinggi dengan gen MHC I ikan lele Afrika (Gambar 5). Sekuen nukleotida produk PCR ukuran sekitar 300 bp identik seba-

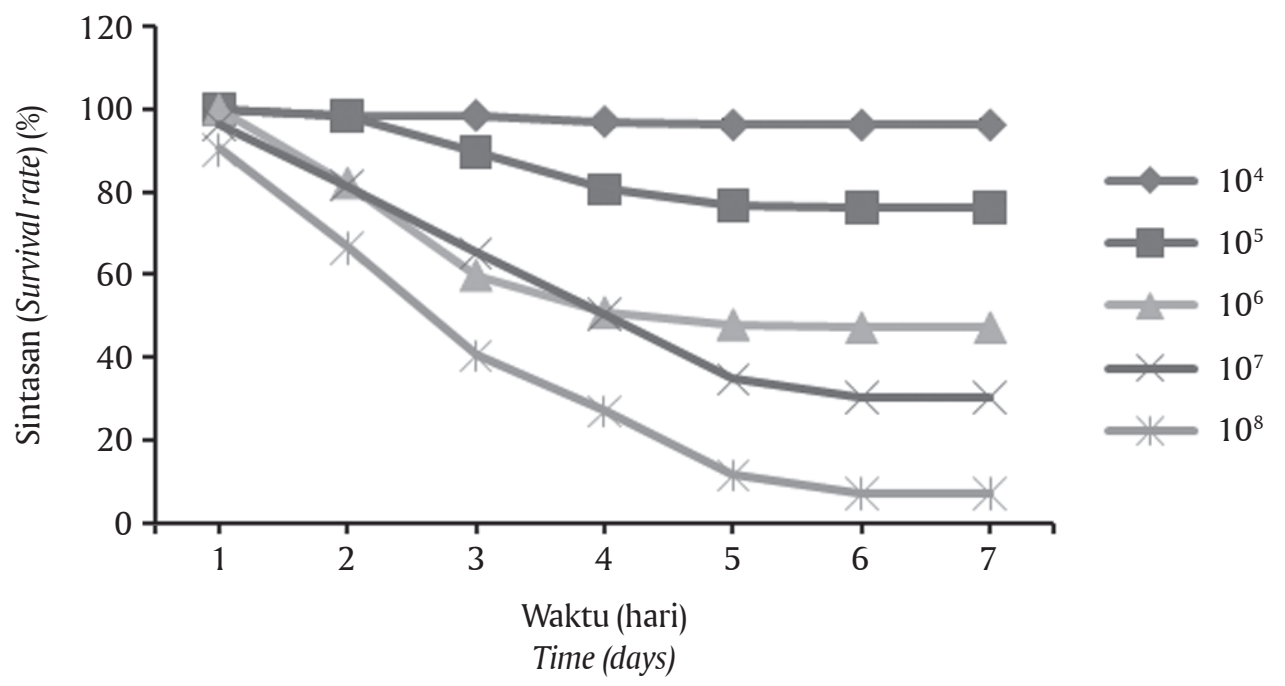

Gambar 1. Sintasan (\%) ikan lele setelah diinfeksi bakteri Aeromonas hydrophila menggunakan dosis LD $_{50}$

Figure 1. Survival rate (\%) of catfish after being infected by Aeromonas hydrophila at $L D_{50}$ level 


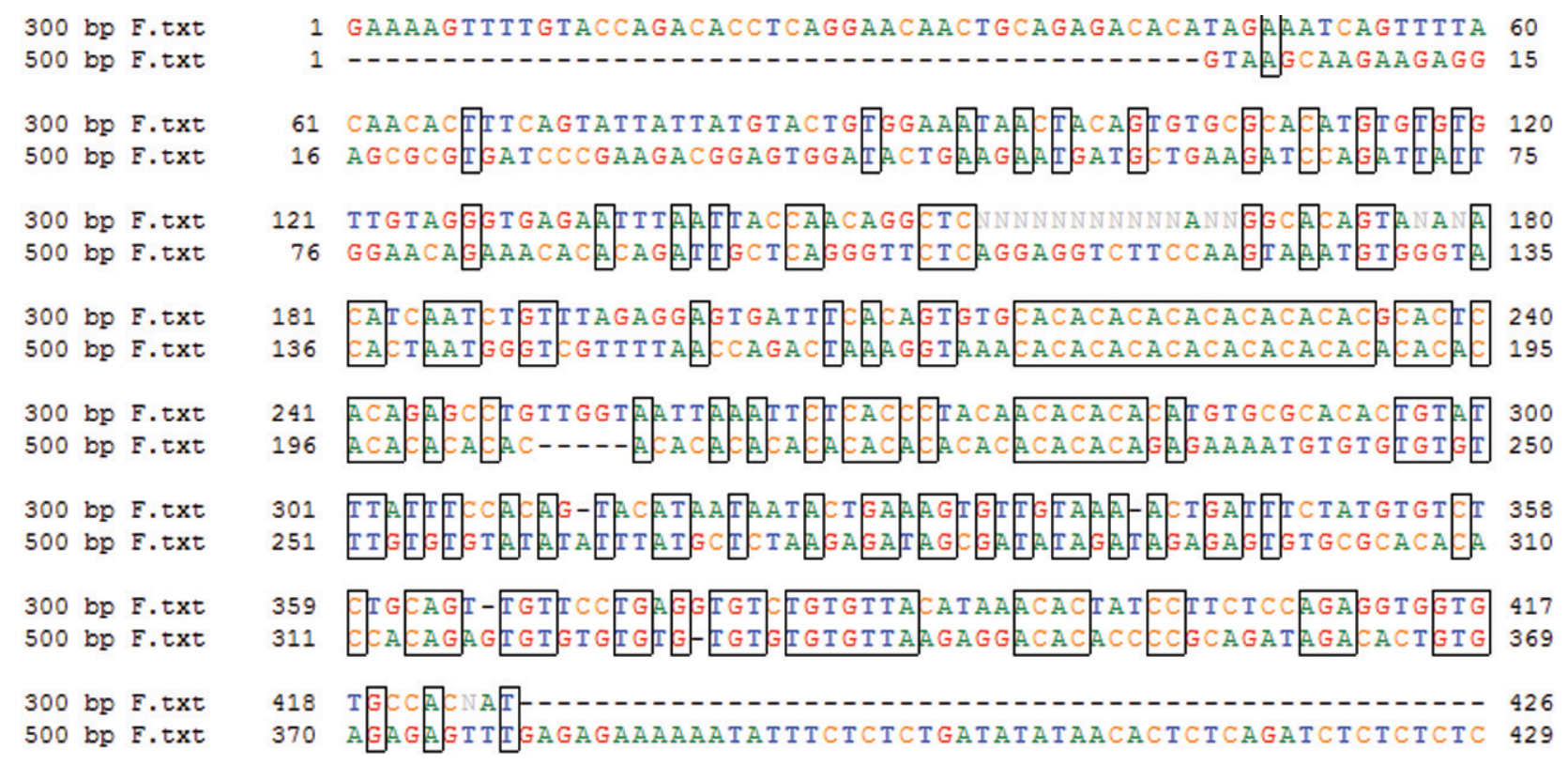

Gambar 4. Penyejajaran nukleotida produk PCR pada pita DNA berukuran sekitar 300 bp dengan 500 bp yang spesifik terdapat pada ikan lele sangkuriang (Clarias sp.) bertahan hidup dalam uji tantang dengan bakteri Aeromonas hydrophila

Figure 4. Nucleotide alignment of PCR product of about $300 \mathrm{bp}$ with $500 \mathrm{bp}$ DNA fragment in the survived sangkuriang catfish (Clarias sp.) post-challenged with Aeromonas hydrophila

\begin{tabular}{|c|c|c|c|c|c|c|}
\hline Description & score s & scove & cover & value & Went & Accession \\
\hline Clarias qarieginus IHC dass I anbeen (Claa UAA) mRNA Clea-UA409 allele, partial ods & 55.4 & 55.4 & $7 \%$ & $3 e-09$ & $84 \%$ & EU714310.1 \\
\hline Description & $\begin{array}{l}\text { Max } \\
\text { scoute s }\end{array}$ & $\begin{array}{l}\text { Total } \\
\text { sctore }\end{array}$ & $\begin{array}{l}\text { Queny } \\
\text { cover }\end{array}$ & $\begin{array}{c}\mathrm{E} \\
\text { value }\end{array}$ & Ident & Accession \\
\hline 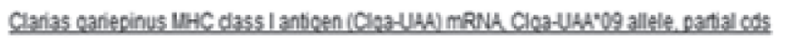 & 232 & 232 & $22 \%$ & 4e-62 & $79 \%$ & EU714310 \\
\hline 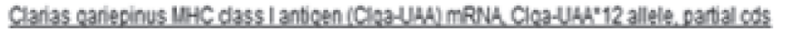 & 226 & 226 & $22 \%$ & $20-60$ & $78 \%$ & EU714313.1. \\
\hline 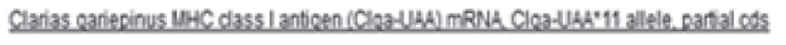 & 217 & 314 & $34 \%$ & 9e.58 & $78 \%$ & EU7143121 \\
\hline 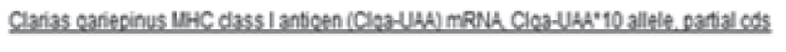 & 212 & 309 & $34 \%$ & $4 e-56$ & $77 \%$ & EU7143111 \\
\hline 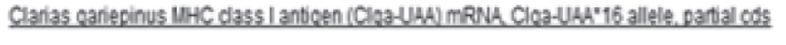 & 203 & 203 & $22 \%$ & 2e-53 & $77 \%$ & EU714317: \\
\hline 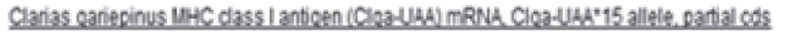 & 203 & 203 & $22 \%$ & 2e.53 & $77 \%$ & EU714316: \\
\hline Description & $\begin{array}{l}\text { Max } \\
\text { score }\end{array}$ & $\begin{array}{l}\text { Total } \\
\text { score }\end{array}$ & $\begin{array}{l}\text { Query } \\
\text { cover }\end{array}$ & $\underset{\substack{E \\
\text { value }}}{E}$ & Ident & Accession \\
\hline 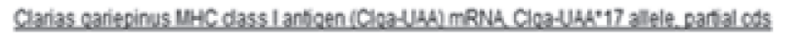 & 197 & 283 & $25 \%$ & $10-51$ & $86 \%$ & EU714318.1 \\
\hline 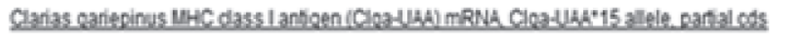 & 136 & 136 & $9 \%$ & $30-33$ & $79 \%$ & EU714316: \\
\hline 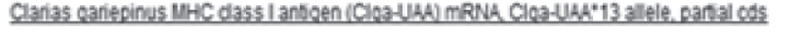 & 136 & 136 & 9\% & 30.33 & $79 \%$ & EU714314. \\
\hline 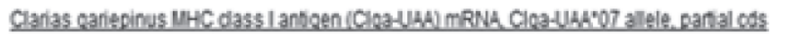 & 122 & 122 & $9 \%$ & $70-29$ & $77 \%$ & EU714209: \\
\hline 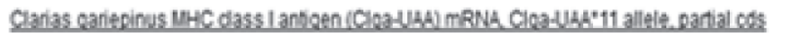 & 100 & 100 & $8 \%$ & 20.22 & $74 \%$ & EU714312: \\
\hline
\end{tabular}

Gambar 5. Analisis BLAST sekuen nukleotida produk PCR pita DNA berukuran sekitar $300 \mathrm{bp}$ (A), 500 bp (B) dan 1.000 bp (C) dari ikan lele sangkuriang (Clarias sp.) bertahan hidup dalam uji tantang bakteri Aeromonas hydrophila. Description adalah deskripsi alel MHC I C. Gariepinus; Max. score adalah nilai maksimum; total score adalah nilai total; identity adalah nilai kemiripan

Figure 5. BLAST analysis of the nucleotide sequences of PCR amplification of approximately $300 \mathrm{bp}$ (A), $500 \mathrm{bp} \mathrm{(B)} \mathrm{and} \mathrm{1,000} \mathrm{bp} \mathrm{(C)} \mathrm{of} \mathrm{the} \mathrm{survived} \mathrm{sangkuriang} \mathrm{catfish} \mathrm{(Clarias} \mathrm{sp.)} \mathrm{post-}$ challenged with Aeromonas hydrophila. Description is alel MHC I C. Gariepinus description; Max. score is maximum value; total score is total value; identity is similar value 


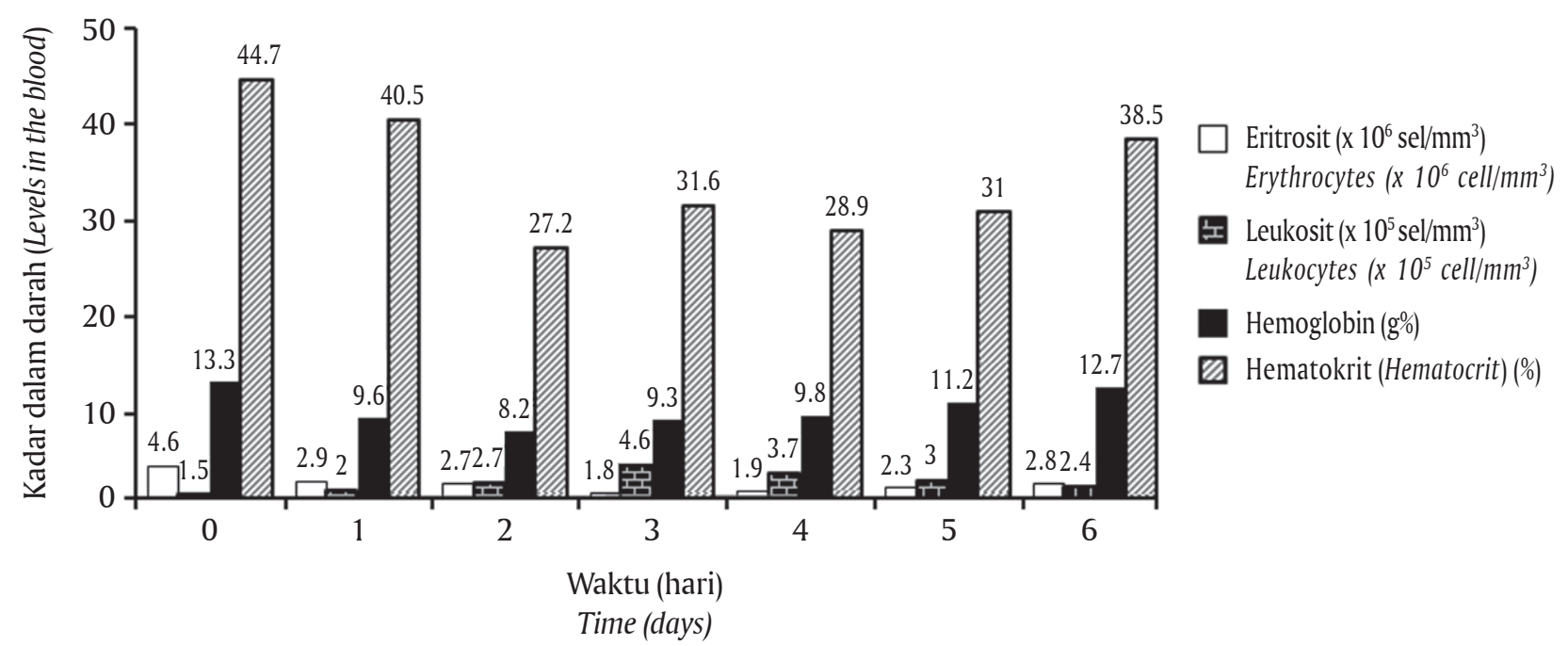

Gambar 6. Kadar eritrosit, leukosit, hemoglobin dan hematokrit ikan lele sangkuriang sebelum (0) hingga hari keenam uji tantang dengan bakteri Aeromonas hydrophila

Figure 6. Levels of erythrocytes, leukocytes, hemoglobin and hematocrit in sangkuriang catfish before (0) and until the sixth days of post-challenged with Aeromonas hydrophila

la (Gambar 2). Namun demikian, produk PCR belum menunjukkan pita DNA tunggal, terdapat tiga pita DNA cukup jelas, yakni sekitar 300 bp, 500 bp, dan 1.000 bp. Dengan demikian dapat diyakini bahwa ikan $\mathrm{R}$ dan LS memiliki gen MHC I terkait daya tahan terhadap A. hydrophila. Keyakinan ini diperkuat dengan hasil analisis BLAST yang menunjukkan bahwa produk PCR ikan lele sangkuriang memiliki kemiripan tinggi dengan MHC I alel 09 dan 17 ikan lele Afrika. Dengan demikian, gen MHC I dapat dijadikan sebagai marka bagi ikan lele sangkuriang yang tahan infeksi A. hydrophila. Selanjutnya, pita DNA produk PCR masih banyak, oleh sebab itu diperlukan penelitian lebih lanjut untuk memastikan alel dan sekuen nukleotidanya secara total, serta untuk mendesain primer spesifik dengan produk pita DNA tunggal.

Hingga saat ini, ikan air tawar termasuk ikan lele sangkuriang, belum ada induk ikan bebas patogen. Oleh karena itu, pewarisan sifat dan uji daya tahan ikan lele terhadap infeksi $A$. hydrophila perlu dilakukan pada generasi berikutnya. Pada ikan mas, telah ditemukan primer Cyca-DAB1*05 untuk mendeteksi ikan mas yang tahan terhadap penyakit koi herpes virus (KHV) dan A. hydrophila, dan telah diuji hingga generasi kedua. Hasil PCR diperoleh bahwa ikan mas F0 yang tahan KHV dan A. hydrophila sebesar 50\%, sedangkan pada $\mathrm{F} 1$ sebanyak $83 \%$ ikan mas tahan KHV dan $A$ hydrophila. Ikan F2 hidup 100\% bila diuji tantang dengan $\mathrm{KHV}$, sedangkan dengan $A$. hydrophila sintasannya 74,4\% (Kepmen KP No. 24/KEPMEN$\mathrm{KP} / 2015)$. Pada ikan nila telah ditemukan MHC I $\alpha$ tahan Streptococcus agalactiae dan berhasil mengidentifikasi sebanyak 15 alel dari enam strain ikan nila (Poonsawat et al., 2009). Ikan nila tahan S. agalactiae juga sedang dikembangkan di Balai Besar Pengembangan Budidaya Air Tawar Sukabumi. Dengan cara yang sama pada ikan mas, besar kemungkinan dapat dicapai hasil yang sama pada ikan lele. Selanjutnya, hasil riset ini juga memberi peluang besar untuk menghasilkan ikan lele sangkuriang tahan infeksi $A$. hydrophila secara massal.

Respons ikan terhadap antigen yang masuk ke dalam tubuh berbeda-beda. Hal ini terlihat dari percobaan yang dilakukan terhadap ikan lele yang diujitantang dengan bakteri $A$. hydrophila. Tiga respons yang berbeda ditemukan, yaitu ikan tidak mengalami luka (sangat tahan, R), ikan luka kemudian sembuh (tahan, LS) dan ikan mati. Adanya perbedaan pita DNA produk PCR, dan respons terhadap uji tantang tersebut menunjukkan kaitan yang kuat antara marka dengan daya tahan ikan lele sangkuriang. Namun demikian, riset lebih lanjut diperlukan untuk menjelaskan lebih detil perbedaan respons tersebut kaitannya jenis alel MHC I pada ikan lele. Sistem pertahanan tubuh pada ikan dipengaruhi oleh kondisi anatomis, fisiologis, spesies, umur, bobot tubuh, dan lingkungan luar sehingga memungkinkan adanya tingkatan yang berbeda-beda (Schaperclaus, 1992). Pada penelitian ini, kondisi ikan yang resisten tidak menunjukkan gejala dropsy, hal ini sangat berbeda pada ikan grup LS di mana terjadi pembengkakan pada hari pertama pascatantang akibat reaksi virulen dari bakteri A. hydrophila. Selanjutnya pada hari kedua pascatantang terjadi ulser di sekitar area penyuntikan. Luka borok pada ikan yang mati tampak semakin lebar pada hari ketiga dan keempat disertai kematian ikan yang tinggi. Untuk ikan grup LS terlihat bahwa area luka pada hari keempat tidak bertambah 
lebar dan hari keenam mulai menunjukkan gejala sembuh dengan adanya semacam lapisan tipis di area luka.

Peningkatan sistem imun pada ikan berkorelasi positif terhadap peningkatan jumlah leukosit darah ikan pascatantang dengan bakteri $A$. hydrophila. Dalam penelitian ini, sebelum ikan terinfeksi $A$. hydrophila jumlah leukosit dalam darah $1,5 \times 10^{5} \mathrm{sel} / \mathrm{mm}^{3}$, dan meningkat secara signifikan pada hari ke-3 pascainfeksi $\left(4,6 \times 10^{5} \mathrm{sel} / \mathrm{mm}^{3}\right)$. Hal ini mengindikasikan bahwa apabila ada antigen masuk ke dalam tubuh, maka leukosit akan memberikan respons dengan meningkatkan jumlahnya sebagai bentuk pertahanan tubuh. Pendapat ini dipertegas oleh Baratawidjaja (2002) yang menyatakan bahwa respons imun akan meningkat dengan cara mengaktifkan leukosit. Penelitian yang dilakukan oleh Bastiawan et al. (2001) menjelaskan bahwa ikan lele dumbo sehat mempunyai kadar leukosit darah $20-150\left(\times 10^{3} \mathrm{sel} / \mathrm{mm}^{3}\right)$, sementara ikan yang terserang endoparasit mengalami peningkatan leukosit hingga $651-742\left(\times 10^{3} \mathrm{sel} / \mathrm{mm}^{3}\right)$.

Masuknya bakteri dalam tubuh mengaktifkan respons imun dengan memproduksi polimorfonuklear leukosit, seperti melano-makrofag, monosit, dan neutrofil yang berperan sebagai pagositik sel. Kehadiran leukosit tersebut menyebabkan bakteri mengeluarkan toksin hemolisin yang mengakibatkan terjadinya ulcer dan hemoragik pada permukaan tubuh ikan (Cipriano, 2001). Ulcer ditemukan pada hari ke-2 sampai hari ke-4 pascatantang $A$. hydrophila, terutama di sekitar tempat injeksi. Hasil penelitian Li et al. (2013) menjelaskan bahwa hemoragik yang terjadi pada pangkal sirip punggung, pangkal sirip ekor dan pangkal sirip perut, disebabkan oleh toksin hemolisin dengan target memecah sel-sel darah merah, sehingga sel keluar dari pembuluh darah, menimbulkan warna kemerahan pada permukaan kulit. Pengamatan gambaran darah menunjukkan terjadinya penurunan jumlah eritrosit dan peningkatan jumlah leukosit pasca terinfeksi $A$. hydrophila, indikasi ini memperlihatkan bahwa sistem imun ikan meningkat akibat adanya antigen yang masuk ke dalam tubuh ikan. Terjadinya ulser disebabkan oleh tingginya kepadatan bakteri pada lokasi tersebut, sehingga volume dan intensitas toksin yang dikeluarkan pada proses infeksi juga lebih tinggi pada bagian tersebut, sementara sebagian lainnya masuk ke dalam tubuh mengikuti aliran darah (Robert, 1993). Sebagai faktor-faktor virulensi, kitinase, lesitinase, dan hemolisin yang dihasilkan oleh $A$. hydrophila, bekerja dengan mendegradasi jaringan dan menimbulkan luka serta pendarahan pada ikan inang (Del Coral et al., 1990).

Berdasarkan Gambar 6, jumlah eritrosit, nilai hematokrit dan kadar hemoglobin $(\mathrm{Hb})$ ikan lele yang terinfeksi A. hydrophyla berada jauh di bawah jumlah eritrosit, nilai hematokrit dan kadar Hb ikan lele sehat (sebelum uji tantang). Penurunan kadar eritrosit, hemoglobin dan hematokrit diduga berkaitan erat dengan jumlah ikan yang mati; rata-rata mortalitas ikan tertinggi juga terjadi pada hari ke-2 sampai hari ke-4 pascatantang bakteri. Diagnosis awal menunjukkan bahwa ikan lele yang terinfeksi mengalami produksi lendir yang berlebih, hal ini menunjukkan adanya mekanisme pertahanan ikan lele terhadap rangsangan bakteri $A$. hydrophila yang menginfeksi ikan lele. Li et al. (2013) menyatakan bahwa lendir pada permukaan kulit ikan adalah sebagai pertahanan terdepan untuk melawan berbagai jenis patogen yang ada di lingkungan perairan. Ikan lele resisten warna tubuhnya abu-abu kehitaman dan mengkilap, sedangkan ikan yang luka warna kulitnya agak pucat dan terdapat bercak kehitaman di sekujur tubuhnya, namun ikan lele luka sembuh pada hari kelima tampak warna kulit sudah mulai berwarna abu-abu kehitaman dan mengkilap.

\section{KESIMPULAN}

Marka molekuler bagi ikan lele sangkuriang yang tahan infeksi bakteri $A$. hydrophila berhasil diperoleh. Ikan lele yang tahan infeksi $A$. hydrophila memiliki produk PCR dengan ukuran sekitar 300 bp, 500 bp dan 1.000 bp. Hasil analisis sekuen menunjukkan bahwa produk PCR tersebut memiliki kemiripan tinggi dengan MHC I alel 9 dan alel 17 ikan lele Afrika.

\section{DAFTAR ACUAN}

Alimuddin, Mubinun, Santika, A., Carman, O., Faizal, I., \& Sumantadinata, K. (2011). Identification of the Majalaya common carp strain resistance to KHV infection using Cyca-DAB1*05 allele as a marker. Indonesian Aquaculture Journal, 6(2), 157163.

Alimuddin, Octavera, A., Arifin, O.Z., \& Sumantadinata, K. (2008). Karakterisasi promotor $\beta$-actin ikan nila (Oreochromis niloticus). Jurnal Akuakultur Indonesia, 7(2), 115-127.

Allan, B.J., \& Stevenson, R.M.W. (1981). Extracellular virulence factors of Aeromonas hydrophila in fish infections. Can. J. Microbiol., 27, 1114-1122.

Angka, S.L., Priosoeryanto, B.P., Lay, B.W., \& Harris, E. (2004). Penyakit motile aeromonad septicemia pada ikan lele dumbo. Forum Pascasarjana. Institut Pertanian Bogor. Bogor.

Aoyagi, K., Dijkstra, J.M., Xia, C., Denda, I., Ototake, M., Hashimoto, K., \& Nakanishi, T. (2002). Classical MHC class I genes composed of highly divergent sequence lineages share a single locus in rainbowtrout (Oncorhynchus mykiss). J. Immunol, 
168, 260-273.

Baratawidjaja, K.G. (2002). Imunologi dasar. Fakultas Kedokteran Universitas Indonesia, $55 \mathrm{hlm}$.

Bastiawan, D., Wahid, A., Alifudin, M., \& Agustiawan, I. (2001). Gambaran darah lele dumbo (Clarias spp.) yang diinfeksi cendawan Aphanomyces sp. pada pH yang berbeda. Jurnal Penelitian Indonesia, 7(3), 44-47.

Blaxhall, P.C., \& Daisley, K.W. (1973). Routine haematological methods for use with fish blood. J. Fish Biol., 5, 771-781.

Choi, S., \& Schwartz, R.H. (2007). Molecular mechanisms for adaptive tolerance and other T cell anergy models. Semin. Immunol., 19(3), 140-52.

Cipriano, R.C. (2001). Aeromonas hydrophila and motile aeromonad septicemia of fish. Fish diseases leaflet 68. United States Department of the Interior Fish and Wild Life Service Division of Fisheries Research Washington DC, 25 pp.

Del Coral, F., Shotts, E.B., \& Brown, J. (1990). Adherence haemagglutination and cell surface characteristics of motile aeromonads virulent for fish. Journal of Fish Diseases, 13, 255-268.

Germain, R.N. (1994). MHC dependent antigen processing and peptide presentation: providing ligands for T lymphocyte activation. Cell, 76, 287299.

Grimholt, U., Drablos, F., Jorgensen, S.M., Hoyheim, B., \& Stet, R.J. (2002). The major histocompatibility class I locus in Atlantic salmon (Salmo salar L.): polymorphism, linkage analysis and protein modelling. Immunogenetics, 54, 570-58.

Keputusan Menteri Kelautan Dan Perikanan Republik Indonesia No. 24/KEPMEN-KP/2015 tentang Pelepasan Ikan Mas Mantap, $6 \mathrm{hlm}$.

Kirpichnikov, V.S. (1999). Genetics and breeding of common carp. INRA editions, Paris.

Kirpichnikov, V.S., Ilyasof, J.I., Shart, L.A., Vikhman, A.A., Ganchenko, M.V., Ostahevsky, A.L., Simonov, V.M., Tikhonov, G.F., \& Tjurin, V.V. (1993). Selection of Krasnodar common carp (Cyprinus carpio) for resistance to dropsy: principal result and prospects. Aquaculture, 111, 7-20.

Kjoglum, S., Larsen, S., Bakke, H.G., \& Grimholt, U. (2006). How specific MHC class I and class II combinations affect disease resistance against infectious salmon anaemia in Atlantic salmon (Salmo salar). Fish Shellfish Immunol., 21, 431-441.

Li, C., Wang, R., Su, B., Luo, Y., Terhune, J., Beck, B., \& Peatman, E. (2013). Evasion of mucosal defenses during Aeromonas hydrophila infection of channel catfish (Ictalurus punctatus) skin. Developmental and Comparative Immunology, 39, 447-455.
Mulia, D.S., Pratiwi, R., \& Triyanto. (2004). Efikasi vaksin debris sel Aeromonas hydrophila secara suntik dengan variasi cara booster pada lele dumbo (Clarias gariepinus Burchell). Berkala Ilmiah Biologi, 3(3), 145-156.

Poonsawat, S., Areechon, N., Srisapoome, P., Maita, M., \& Endo, M. (2009). Polymorphism of major histocompatibility complex class I alpha cDNA and resistance against streptococcosis of six strains of Nile tilapia (Oreochromis niloticus Linnaeus). Kasetsart J. (Nat. Sci.), 43: 348-357.

Rakus, K.L. (2008). Major histocompatibility (MH) polymorphism of common carp link with disease resistance. PhD Thesis. Cell Biology and Immunology Group, Wageningen Institute of Animal Sciences, Wageningen University. Netherlands, 169 pp.

Reed, L.J. \& Muench, H. (1938). A simple method of estimating fifty per cent endpoints. American Journal of Hygiene, 27, 493-497.

Robert, R.J. (1993). Motil Aeromonad Septicemia. Bacterial diseases of fish. Institute of Aquaculture. Blackwell Science Ltd, USA, p. 143-156.

Roitt, I. (1994). Essential immunology, 8/E. Arrangement with Blackwell Science limited, Oxford, p. 67-73.

Schaperclaus, W. (1992). Fish Disease. Vol 1. Ed. W. Schaperclaus, H. Kulow, K. Schreckenbach, a.A. balkema. Roterdam, 596 pp.

Siwicki, A.K., \& Anderson, D.P. (1993). Nonspecific defence mechanisms assay in fish: II. Potential killing activity of neutrophils and macrophages, lysozyme activity in serum and organs. In: Siwicki, A.K., Anderson, D.P., \& Waluga, J. (Eds.), Disease Diagnosis and Prevention Methods, FAO-Project GCP/INT/526/JPN, IFI, Olsztyn, p. 105-111.

SNI. (2009). Metode identifikasi bakteri Aeromonas hydrophila secara biokimia, SNI 7303:2009.

Wachirachaikarn, A., Na-Nakorn, U., Rungsin, W., \& Srisapoome, P. (2009). Crossing of African catfish, Clarias gariepinus (Burchell, 1822), strains based on strain selection using genetic diversity data. Aquaculture, 290, 53-60.

Wedenmeyer, G.A., \& Yasutake, W.T. (1977). Clinical methods for the assessment of the effect on environmental stress on fish health. Technical Papers of the U.S. Fish and Wildlife Service. US depert. of the Interior. Fish and Wildlife Service, 89, 1-17.

Xu, T.J., Sun, Y.N., \& Wang, R.X. (2011). Allelic polymorphism, gene duplication and balancing selection of the MHC class II DAB gene of Cynoglossus semilaevis (Cynoglossidae). Genet. Mol. Res., 10(1), 53-64. 